\author{
Д. Каменський, \\ кандидат юридичних наук, доцент, \\ завідувач кафедри правознавства \\ Бердянського державного педагогічного університету
}

\title{
У РОЗВИТОК ДИСКУСІЇ ПРО ВДОСКОНАЛЕННЯ МЕХАНІЗМУ КРИМІНАЛЬНО-ПРАВОВОЇ ОХОРОНИ НАЦІОНАЛЬНОЇ ЕКОНОМІКИ В УМОВАХ ГЛОБАЛІЗАЦІЇ
}

\begin{abstract}
Під час наукового аналізу «економічного» блока положень кримінального права особливу увагу варто приділити вивченню глобалізаційних трендів у сучасному світі, зокрема в міждержавних економічних відносинах. Сьогодні ми всі є свідками притаманних сучасному глобалізованому світу процесів інформатизації, комунікації, стирання мовних бар'єрів, міграції робочої сили та капіталів, спільного освоєння космічного простору, реалізації міжнародних наукових проєктів практично в усіх сферах, транснаціоналізації бізнесу тощо. Ці процеси, які з усією очевидністю набирають дедалі більших обертів, не можуть не впливати, принаймні опосередковано, на право взагалі та кримінальне зокрема. У сучасних суспільствах фіксується поява нових видів економічних злочинів, зростання економічної злочинності загалом та іï адаптація до різноманітних соціально-економічних змін (так звана глобалізація, виникнення нових форм комунікації тощо) [1, с. 370]. Тут, напевне, буде доречним звернутись до слушного твердження голландського дослідника Г. Стессенса про те, що сучасні суспільства все частіше мають справу 3 різновидами економічної злочинності, які не були відомі у XIX ст., коли було сформовано більшість європейських систем кримінальної юстиції. У наш час прокурори та суди на практиці сти-
\end{abstract}

каються 3 феноменами економічної злочинності, які раніше взагалі не існували. Значна роль у цих процесах належить корпораціям, оскільки левова частка ділової активності в сучасному світі припадає саме на корпоративний бізнес [2, с. 493].

Варто наголосити на тому, що представники вітчизняної кримінально-правової доктрини серйозно оцінюють як позитивні аспекти, так і загрози глобалізації в контексті еволюції підходів до кримінально-правової охорони суспільних відносин. Показовим прикладом у цьому сенсі $€$ проведена 12-13 жовтня 2017 р. в м. Харкові Міжнародної науково-практичної конференції «Кримінально-правове забезпечення сталого розвитку України в умовах глобалізаціі», яка зібрала понад 240 науковців із декількох європейських країн. На цьому заході обговорювалися багато дискусійних питань, серед яких: теоретичні та методологічні засади реформування кримінального законодавства України в умовах глобалізації; джерела формування міжнародного кримінального права та його місце в національній правовій системі; нові й оновлені загрози сталому розвитку України в умовах глобалізації та підстави для введення чи вдосконалення заходів відповідної кримінально-правової протидії; упровадження позитивного міжнародного досвіду у сфері кримінального права 
у вітчизняну законотворчу та правозастосовну практику; кримінально-правові проблеми боротьби із транснаціональною злочинністю та корупцією на національному та міжнародному рівнях; питання кримінальної відповідальності за міжнародні злочини; актуальні проблеми наук кримінально-правового циклу в умовах євроінтеграції [3, с. 673].

Щодо власне галузевого акценту в дослідженнях феномену правової глобалізації, принагідно зверну увагу на те, що в Декларації міжнародного форуму із проблем злочинності й кримінального права в епоху глобалізації, до роботи якого у грудні 2012 р. долучився $M$. Хавронюк, ключову увагу приділено саме тенденціям розвитку кримінальної-правової науки в наднаціональному вимірі та в умовах необхідності реагування на кримінальні загрози дедалі більш помітної глобалізаціі. Уважаю за доречне звернутись до деяких ключових тез у тексті цього документа. По-перше, настання епохи глобалізації $€$ новим етапом і «відправною точкою» розвитку кримінального права та юриспруденціі. По-друге, сьогодні стає очевидним, що суто національному курсу еволюції теорії кримінального права не вистачає глобального бачення реальності, оскільки початкові та кінцеві цілі такого розвитку є обмеженими. По-третє, епоха глобалізації вимагає оновлення ідей та методології наукових досліджень. Вивчення розвитку кримінального права у всесвітньому масштабі охоплює та слугує інтересам не лише окремих держав, а водночас має сприяти вдосконаленню міжнародного кримінального права. Наукова методологія в цій частині повинна забезпечувати всебічний аналіз глобального дослідження, а також брати до уваги національну теорію кримінального права як фундаментальну частину глобальної теорії й практики. По-четверте, теорія кримінального права поки що залишатиметься національною, незважаючи на те, що вона вже охоплює деякі сфери глобалізованого світу - отже, «стартовим майданчиком» сучасних кримінально-правових досліджень повинна виступати національна теорія кримінального права; водночас поступово упродовж свого подальшого розвитку вона буде дедалі більше охоплювати процеси глобального усвідомлення реальності. По-п'яте, глобалізація злочинності та кримінального права вимагає від фахівців та вчених різних країн посилити міжнародне співробітництво та постійний обмін думками щодо важливих теоретичних і практичних проблем [4, с. 109-110].

Текст згаданого документа, відштовхуючись від динамічних реалій розвитку злочинності та заходів протидії ій у сучасному світі, розкриває перед фаховою спільнотою світу нові горизонти недалекого майбутнього, у якому категорії «злочин» i «покарання», вочевидь, остаточно вийдуть за межі національного суверенітету та стануть проявами повсякденної (якщо не сказати рутинної) діяльності для законодавців, правоохоронців, адвокатів і суддів.

На думку В. Тулякова, глобалізаційні тренди породжують наднаціональне кримінальне право та кримінально-процесуальні відносини, що поширюються на злочини проти миру та безпеки людства, транснаціональну організовану злочинність у формах незаконного обігу людських ресурсів, капіталів, зброї та наркотиків, предметів культурної спадщини, урешті-решт, на системну корупцію та комп'ютерну злочинність. Вартує підтримки позиція вченого в тому, що глобалізаційні процеси наділяють порівняльний метод у кримінальному праві інструментальним статусом системного наукового дослідження [5, с. 29, 40].

Оригінальну авторську позицію щодо визначення «точок зіткнення» між вітчизняним кримінальним правом і процесами глобалізації обстоює О. Житний. Він переконує в тому, 
що зміни у «кримінальній картині світу», спричинені саме глобалізацією, потребують вивчення в межах кримінально-правової доктрини, а також повинні враховуватись у правотворчій діяльності - зокрема під час вирішення питань криміналізації й декриміналізації, пеналізації, удосконалення засобів кримінально-правового впливу та під час вирішення інших проблем науки кримінального права [6, с. 102]. Звертаючи увагу на процеси глобалізації у світі, які сприяють поступовому підвищенню рівня універсалізації національних законодавств різних держав, О. Дудоров i T. Тертиченко слушно вказують на поступове приєднання українського законодавства до розвитку таких тенденцій, зокрема в межах традиційної галузі кримінального законодавства [7, с. 90]. Частково питання взаємодії норм кримінального права та процесів економічної глобалізації досліджував і автор цієї статті [8, с. 4-5].

На сучасному етапі позитивними проявами глобалізації, які впливають на кримінальне право, варто визнати тенденції конвергенції (зближення) держав і правових систем, зокрема й у сфері кримінального права. Євроатлантичний напрям розвитку України є чітким і визначальним орієнтиром для подальшого розвитку вітчизняного кримінального законодавства в аспекті сприйняття позитивного і кращого досвіду боротьби зі злочинністю. Поряд із цим указаний розвиток повинен пов'язуватись зі збереженням кращих досягнень науки i практики вітчизняного кримінального права та традицій кримінального законотворення. Варта підтримки теза про те, що зближення правових систем i національних законодавств повинно базуватися на ідеях правової держави та верховенства права, які визнаються в Україні конституційними принципами та які на рівні правотворчої діяльності повинні реалізовуватися через систему принципів кримінального права [3, с. 686-687].
Нині глобалізація проявляється в різних сферах життя держави та суспільства, що перебувають під впливом права, змінюють суспільні відносини, які $€$ предметом кримінально-правової охорони та кримінально-правового регулювання. А тому без урахування чинника глобалізації під час організації й реалізації кримінальної політики неможливо гармонійно узгодити національні засоби соціально-правового контролю над злочинністю 3 міжнародними підходами та стандартами [9, с. 45-46].

В. Попко також констатує, що глобалізація як світова тенденція новітнього часу має як позитивний вплив на розвиток національного й міжнародного права (постійний процес зближення змісту правового регулювання й зовнішніх форм його вираження, запозичення закордонного досвіду, творче врахування позитивних рис правових систем інших країн, гармонізація внутрішньодержавного кримінального права), так і негативний. Одним із найбільш серйозних негативних наслідків глобалізації дослідник, вочевидь небезпідставно, визнає зростання злочинності у світі, а також виникнення нових, більш масштабних і більш небезпечних форм злочинності, яка не обмежується національними кордонами та набуває транснаціонального характеру [10, с. 241-242].

Україна відчула вплив глобалізації вже з перших років незалежності, коли іï економіка, валютно-фінансова система та соціальна сфера стали відкритими для всього світу та насамперед для країн, які уособлюють умовно авангард глобалізації. Дедалі втягуючись у процес глобалізації, Україна, з одного боку, має всі шанси скористатись їі перевагами, а з іншого - стає більш відкритою для нових викликів і загроз, які вимагають швидкого реагування [11, с. 466-467].

До речі, глобалізації властива лібералізація фінансових операцій. Тому $є$ підстави для висновку про 
те, що проведену у 2011 р. декриміналізацію ухилення від повернення виручки в іноземній валюті (раніше ст. 207 Кримінального кодексу (далі - KK)) та незаконного відкриття або використання за межами України валютних рахунків (ст. 208 KK) можна пов'язати із впливом глобалізації на вітчизняний фінансовий ринок [9, с. 50].

Під час запропонованої характеристики, бодай і дотичної, процесів загальноправової (зокрема, кримінально-правової) глобалізації в сучасному світі, не можна залишити поза увагою глобалізацію економічну феномен, який набуває тут особливого значення. Так, сучасні західні теорії глобалізації активно описують макропроцеси соціально-економічно розвитку періоду «Великого транзиту» (1970-і - 2000-і рр.) - періоду, коли між окремими країнами та навіть регіонами світу істотно зросли товарообіг і рух капіталу.

У цьому контексті варто згадати вдале висловлювання О. Бойцова, який у відомій праці «Злочини проти власності» коментує міжюрисдикційні економічні зв'язки: наскільки б досконало не була влаштована та чи інша економічна система, реальне іï функціонування багато в чому залежить від іiі взаємодії з іншими економічними системами, зі світовою економікою загалом. Отже, учений додає, що не менш важливою функцією публічної влади залишається забезпечення гармонійних зв'язків між національною економічною системою й економічними системами інших країн, з регіональними економічними системами спільнот держав, а також із глобальною, світовою економічною системою [12, c. 18].

Економічна глобалізація означає процес структурних змін і поетапного формування органічно цілісного світового господарства як необхідного елемента становлення та розвитку цілісності світового суспільства. В. Савчук i Ю. Зайцев слушно додають, що створення національної ринкової економіки означає, серед іншого, перетворення іï на складову частину світового ринкового господарства, а отже, породжує залежність від сучасних тенденцій його розвитку, залежність від інституцій, механізмів та інструментів, якими оперує світовий ринок. На цьому тлі нагальною потребою стають визначення основних форм співпраці нашої держави з міжнародними фінансово-кредитними та торговельними організаціями, регіональними об'єднаннями країн, участь у спільних 3 іншими країнами економічних проєктах і програмах тощо [13, с. 428].

На відносини між суб'єктами економічної діяльності суттєво впливають не лише процеси розвитку формалізованих ринкових відносин, а й чимало неформальних, неекономічних за своїм змістом чинників, соціокультурне середовище, морально-етичний клімат у суспільстві тощо. Особливого значення ці чинники набувають в умовах перехідної економіки, що й відбивається на сучасних процесах становлення української економіки. Тут ринок постає не як самодостатній чинник, здатний розв'язати суспільні проблеми, а лише як один із механізмів суспільства, який пронизує всю сукупність суспільних відносин і безпосередньо залежить від соціально-політичної сфери, історичної та культурної спадщини [14, с. 287, 292].

Отже, під правовою глобалізацією потрібно розуміти створення системи норм та міждержавної, міжнародної правової системи, що організовують, забезпечують, узгоджують глобальну взаємодію в різних сферах суспільства шляхом взаємодії міжнародного й національного права, із залученням норм корпоративного права, транснаціональних суб'єктів світової економіки, наднаціональних економічних і фінансових норм і правил діяльності держав, міждержавних союзів, загальновизнаних правових стандартів і цінностей [11, с. 464]. Як убачається 


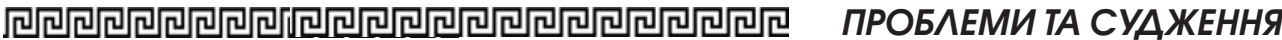

з наведеної дефініції, однією зі складових частин умовного «фундаменту» цього явища є саме економічні відносини в міждержавному контексті.

На думку відомого вітчизняного теоретика права П. Рабіновича, процес глобалізації предмета юридичної науки актуалізував порівняльно-правові дослідження. «Він привів до своєрідного прориву у формуванні вітчизняного порівняльного правознавства як вагомого підрозділу загальнотеоретичної юриспруденціï» [12, с. 17]. У цьому контексті заслуговує на підтримку теза Л. Ребета про те, що здійснювати порівняльно-правові дослідження спонукають суто практичні міркування: міжнародні зв'язки вимагають повного знання закордонного права для налагодження приватно-правових, здебільшого комерційних, відносин; зазначене стосується також процесів закордонної систематизації права та розвитку правової термінологіï [16, с. 63].

у концептуально викладеній статті, присвяченій феномену глобалізації в національній правовій доктрині, В. Стрільчук робить вдалу спробу обгрунтувати факт зростання уваги саме в напрямі юридичних аспектів процесу глобалізації. Сьогодні під вплив глобалізаційних тенденцій, за словами автора, підпадають абсолютно всі сфери життєдіяльності людини й суспільства. Через це відбуваються суттєві, подекуди революційні зміни в економічних, соціальних, політичних, культурних та інших відносинах. Водночас право як один із найважливіших регуляторів суспільних відносин перебуває в органічній єдності 3 тими умовами суспільного життя, у яких відповідні відносини виникають, існують і розвиваються, а тому воно не може не реагувати на ці перетворення $[17$, с. 356,361$]$.

Цілком підтримую висновок згаданого науковця про те, що нині виникає необхідність у грунтовному, системному, комплексному дослідженні тенденцій розвитку саме галу- зевого права (законодавства) в умовах глобалізації. Усебічне осмислення цього феномену на високому науковому рівні, не останньою чергою на рівні галузевих юридичних наук, сприятиме, з одного боку, мінімізаціі негативного впливу процесу глобалізації на різні аспекти життя окремо взятої людини й загалом суспільства, а 3 іншого - утіленню позитивних аспектів глобалізації, зокрема шляхом успішної імплементації загальновизнаних європейських і світових правових стандартів, принципів і цінностей.

Американський експерт із питань кримінально-правової протидії «білокомірцевій» злочинності Л. Дерван звертається до актуального прикладу глобалізованого, наднаціонального характеру сучасної економічної злочинності.

У квітні 2010 р. російські правоохоронні органи провели обшуки в московському офісі американської компаніiі "Hewlett Packard" (далі "НР") - усесвітньо відомого виробника електроніки. Проведені слідчі дії були спрямовані на виявлення документальних підтверджень корупційної схеми, яка, за версією слідства, полягала в тому, що працівники німецького офісу компаніі виплачували систематичні винагороди («відкати») російським чиновникам за право реалізувати контракт вартістю 35 млн євро на розробку і встановлення системи інформаційного забезпечення в органах прокуратури Російської Федерації. Уже у вересні 2010 р. головний офіс компаніі "НР" повідомив у документах публічної звітності про те, що розпочате в Росії розслідування набуло міжнародного масштабу - відтепер воно здійснювалось представниками Міністерства юстиції Сполучених Штатів Америки та Комісії із цінних паперів і фондового ринку й охоплювало представництва американської компанії у дванадцяти країнах, зокрема у Федеративній Республіці Німеччина, Росіі, Австрії, Сербіі та Нідерландах [18, с. 362-363]. 
На цьому прикладі можемо спостерігати прямий зв'язок між сучасними глобалізованими умовами ведення бізнесу, насамперед великого (корпоративного), та не менш «глобалізованою», наднаціональною реакцією на них із боку правоохоронних відомств різних країн світу в релевантних ситуаціях. Інший американський дослідник, М. Хаусфелд, констатує, що глобалізація комерції збільшила економічну взаємозалежність держав у світі. Інтеграція ринків, що дедалі зростає, принесла збільшення кількості та поширеність випадків антиконкурентних узгоджених дій, які впливають на сценарії розвитку світової економіки [19, с. 9]. Британський учений Б. Загаріс пише, що сучасна економіка, глобалізація та нові технології сприяють поширенню транснаціональної злочинності і, не останньою чергою, злочинності економічної [20, с. 2].

Цю думку розвиває В. Хилюта, коли описує конкретну i водночас досить типову ситуацію еволюції економічної злочинності в епоху глобалізації: глобалізація світової економіки й ефективність ринків капіталу, що зростає, дозволяють фізичним і юридичним особам переміщувати величезні суми грошей як на внутрішніх фінансових ринках, так і 3 однієї країни в іншу. Така ефективність і відносна безконтрольність руху грошових коштів надають кримінальним елементам можливість безкарно «відмивати» кошти. Через це нині легалізація доходів, отриманих злочинним шляхом, фактично набула характеру міжнародних фінансових операцій [21, c. 137].

Як висновок, що узагальнює наведені в попередніх рядках положення, варто зафіксувати, що сучасні глобалізаційні тренди впливають на процеси перманентного зближення кримінального права окремих країн. Це актуалізує ретельне вивчення питань про часткове змішування норм кримінального права як на рівні правових сімей, так і, більш предметно, на рівні правових систем окремих держав.

Навіть більше, феномен глобалізаціï значною мірою актуалізує порівняльно-правові дослідження в галузі кримінального права. Такий зв'язок між окремою науковою дисципліною та конкретним явищем зумовлений суто прагматичними міркуваннями: на карті сучасного світу відбуваються важливі зміни в економічних, соціальних, політичних, культурних та інших відносинах між державами, що природно спонукає шукати нових форм кримінально-правового реагування на ці процеси; міжнародні зв'язки, які дедалі посилюються, вимагають належного рівня обізнаності із закордонним правом та його коректного співвідношення із правом національним, особливо з метою налагодження економічних відносин. Водночас поступове стирання економічних кордонів між країнами, створення міждержавних зон вільної торгівлі та вільної конкуренції зумовлює виникнення нових загроз транснаціонального характеру: вивчення релевантних положень кримінального права та кримінального процесу іншої країни стає запорукою ефективного кримінального переслідування осіб, які вчинили координовані злочинні діі на території декількох держав. Нині очевидно, що глобалізація злочинності вимагає від фахівців із різних країн посилення міжнародного співробітництва й обміну науковими ідеями в контексті вирішення актуальних теоретико-прикладних проблем протидіі злочинним проявам на міждержавному рівні.

У статmі запропоновано аргументи на користь авторської ідеї про напрями вдосконалення механізму кримінально-правової охорони вітчизняної економіки в умовах світової глобалізації. Показано вплив процесів інформатизації, комунікації, стирання мовних бар'єрів, 
міграцї робочої сили та капіталів, спільного освоєння космічного простору, реалізації міннародних наукових проєктів практично в усіх сферах, транснаціоналізації бізнесу тощо. Установлено, що позначені прочеси, які з усією очевидністю набирають дедалі більших обертів, не можуть не впливати, принаймні опосередковано, на право взагалі та кримінальне зокрема. Констатовано, що в сучасних суспільствах фіксується поява нових видів економічних злочинів, зростання економічної злочинності загалом та ї адаптація до різноманітних соиіально-економічних змін.

Підтримано висловлену в літературі позицію про те, що нині виникае необхідність у трунтовному, системному, комплексному дослідженні тенденцій розвитку саме галузевого права (законодавства) в умовах глобалізаиіі. Визначено, що всебічне осмислення цього феномену на високому науковому рівні, не останньою чергою на рівні галузевих юридичних наук, сприятиме, з одного боку, мінімізації негативного впливу прочесу глобалізації на різні аспекти життя окремо взятої людини й загалом суспільства, а з іншого - утіленню позитивних аспектів глобалізаціі, зокрема шляхом успішної імплементації загальновизнаних європейських $i$ світових правових стандартів, принципів $i$ иінностей.

Обтрунтовано висновок про те, що сучасні глобалізаційні тренди впливають на проиеси перманентного зближення кримінального права окремих держав. Цей тренд актуалізуе ретельне вивчення питань про часткове змішування норм кримінального права як на рівні правових сімей, так $i$, більш предметно, на рівні правових систем окремих держав. Також констатовано, що феномен глобалізації значною мірою актуалізуе порівняльно-правові дослідження в галузі кримінального права.

Ключові слова: глобалізація, злочинність, кримінальне право, юридична компаративістика.

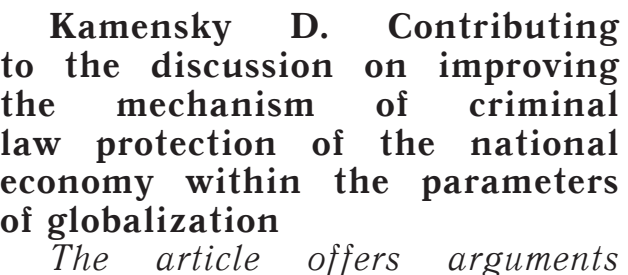
supporting the author's idea of means to improve the mechanism of criminal protection of the domestic economy in the context of globalization. The influence of the processes of informatization, communication, erasure of language barriers, migration of labor and capital, joint development of outer space, implementation of international research projects in almost all areas, transnationalization of business, etc. is demonstrated. It has been established that such processes, obviously gaining momentum, cannot but affect, at least indirectly, the law in general and criminal law in particular. It is stated that in modern societies, the emergence of new types of economic crimes, the growth of economic crime in general and its adaptation to various socio-economic changes take place.

The position, expressed in legal literature, is supported that today there is a need for a thorough, systematic, comprehensive study of trends in the development of industry law (legislation) in the context of globalization. It is determined that a comprehensive understanding of this phenomenon at a high scientific level, not least at the level of branch legal sciences, will help, on the one hand, minimize the negative impact of globalization on various aspects of life and society as a whole, and on the other - the implementation of positive aspects of globalization, in particular 
through the successful implementation of universally recognized European and world legal standards, principles and values.

The conclusion that modern globalization trends influence the processes of permanent convergence of criminal law of individual states is substantiated. This trend highlights a careful study of issues of partial mixing of criminal law at the level of the legal families, and, more specifically, at the level of legal systems of individual states. It is also stated that the phenomenon of globalization significantly actualizes comparative legal research in the field of criminal law.

Key words: globalization, crime, criminal law, legal comparative studies.

\section{Література}

1. Жалинский А. Избранные труды. Москва : Издательский дом Высшей школы экономики, 2015. Т. 2 : Уголовное право. 592 с.

2. Stessens G. Corporate Criminal Liability: A Comparative Perspective. International \& Comparative Law Quarterly. 1994. № 43. P. 493-520.

3. Борисов В., Євтєєва Д. Кримінально-правове забезпечення сталого розвитку України в умовах глобалізації. Вісник Асоиіації кримінального права України. 2017. № 2 (9). С. 673-693.

4. Хавронюк М. Декларация международного форума по проблемам преступности и уголовного права в эпоху глобализации (МФППУПЭГ). Підприємництво, господарство $і$ право. 2013. № 1. C. 109-110.

5. Туляков В. Порівняльний метод $у$ науці кримінального права. Вісник Асоціації кримінального права України. 2014. № 1. URL: http: / / nauka.nlu.edu.ua/ wp-content / uploads / 2015/07/2_3.pdf (дата звернення: 11.11.2020).

6. Житний О. Адаптація кримінального права України до умов глобалізації: деякі проблеми $і$ перспективи. Проблеми науки кримінального права та їх вирішення у законотворчій та правозастосовній діяльності : матеріали Міжнародної науково-практичної конференції, 8-9 жовтня 2015 р. Харків. С. 100-105.
7. Дудоров О., Тертиченко Т. Обумовленість вдосконалення кримінального законодавства України законодавством Ради Європи та Європейського Союзу. Наука кримінального права в системі міждисииплінарних зв'язків : матеріали Міжнародної науково-практичної конференції, 9-10 жовтня 2014 р. / редкол. : В. Тацій (голов. ред.) та ін. Харків : Право, 2014. С. 89-94.

8. Kamensky D. The Third Global White Collar Crime Institute: Pressing Issues \& Enforcement Frontiers. Criminal Justice Section Newsletter. Fall 2019. P. 4-5. URL: https: / / www.americanbar.org / content / dam/aba/publications/ criminal_justice_ section_newsletter/newsletter_fall2019.pdf (дата звернення: 11.11.2020).

9. Житний О. Глобалізація та функиії кримінального права України (окремі питання). Вісник Кримінологічної асоціації України. 2014. № 6. C. 45-53.

10. Попко В. Суспільні передумови та роль глобалізації у формуванні транснаціонального кримінального права. Підприємництво, господарство і право. 2019. № 8. C. 236-243.

11. Велика українська юридична енциклопедія : у 20-и т. Харків : Право, 2016. T. 3 : Загальна теорія права / редкол. : О. Петришин (гол.) та ін. ; Нац. акад. прав. наук України ; Ін-т держави i права імені В.М. Корецького НАН України ; Нац. юрид. ун-т імені Ярослава Мудрого. 2017. 952 c.

12. Бойщов А. Преступления против собственности. Санкт-Петербург : Юридический иентр «Пресс», 2002.775 c.

13. Перехідна економіка : підручник / В. Геєць та ін.; за ред. В. Гейияя. Киїь : Вища школа, 2003. 591 с.

14. Чухно А. Сучасні економічні теорії : підручник / за ред. А. Чухна. Київ : 3нання, 2007. 878 c.

15. Рабінович П. Методологія вітчизняного загальнотеоретичного праводержавознавства: деякі сучасні тенденції. Право України. 2014. № 1. С. 11-21.

16. Ребет Л. Порівняльна метода в науці права / упоряд. і наук. ред. О. Кресіна, I. Кресіної. Київ ; Мюнхен : Український вільний університет ; Центр порівняльного правознавства Iнституту держави $і$ права ім. В.М. Корещького НАН України. Київ : Логос, 2017. $231 \mathrm{C}$.

17. Стрільчук В. Феномен глобалізації в національній правовій доктрині.

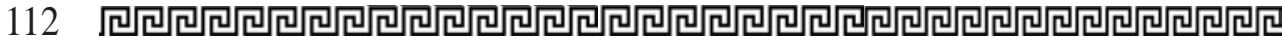




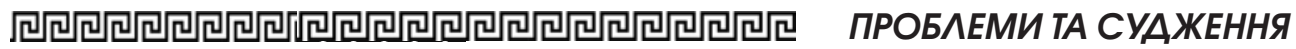

Наукові праці Національного університету «Одеська юридична академія». 2015. T. XVI. C. 354-363.

18. Dervan L. International White Collar Crime and the Globalization of Internal Investigations. Fordham Urban Law Journal. 2011. № 39. P. 361-389.

19. Hausfeld M. Global Enforcement of Anticompetitive Conduct. Sedona Conference Journal. 2009. № 10. P. 9-27.
20. Zagaris B. International Enforcement Law Trends for 2010 and Beyond: Can the Cops Keep Up with the Criminals? Suffolk Transnational Law Review. 2011. № 34. P. 1-45.

21. Хилюта В. Преступления против порядка осуществления экономической деятельности: проблемы правотворчества и правоприменения : монография. Гродно : ГрГУ, 2014. 456 с. 